\title{
An inventory of river anomalies in the Po Plain, Northern Italy: evidence for active blind thrust faulting
}

\author{
Pierfrancesco Burrato, Francesca Ciucci and Gianluca Valensise \\ Istituto Nazionale di Geofisica e Vulcanologia, Roma, Italy
}

\begin{abstract}
The Po Plain is a low-relief area characterised by active shortening accommodated by blind thrust faulting. In this almost flat region depositional rates are similar to tectonic rates and deformation is seldom expressed by noticeable surface anticlines. We adopted a geomorphological approach based on the detailed analysis of the drainage network to identify the location of active thrust faults. A total of 36 anomalies represented by sudden river diversions and shifts in channel pattern were accurately mapped. After comparison with the location of subsurface buried anticlines and of historical seismicity, these anomalies could be related to a tectonic origin and included in a database. Their distribution highlights the activity of the buried outer thrust fronts of both the Southern Alps and the Northern Apennines. Among all the anomalies, we identified one related to the seismogenic source responsible for the 12 May 1802 earthquake $\left(M_{e} 5.7\right)$, which struck the Oglio River Valley near Soncino (Cremona). We propose that this earthquake was generated by an east-west trending, north-dipping, blind thrust fault that roots into the Alpine system. If this inference is correct, other faults along the Southern Alpine margin are potentially seismogenic.
\end{abstract}

Key words tectonic geomorphology - drainage anomaly - blind thrust - Po Plain - 1802 Oglio Valley earthquake

\section{Introduction}

Alluvial plains are among the most densely populated areas worldwide. This is the result of a combination of morphological, hydrological and geological factors that make them advantageous for human settlements. However, often they are located in active regions, and their flat surface resulting from a high sediment supply from nearby high relief areas may hide blind faults posing a significant seismic hazard. A

Mailing address: Dr. Pierfrancesco Burrato, Istituto Nazionale di Geofisica e Vulcanologia, Via di Vigna Murata 605, 00143 Roma, Italy; e-mail: burrato@ingv.it striking example is the Los Angeles basin in California, located at the transform Pacific margin of the North American plate (Wright, 1991). Here more than 12 million people live in an area prone to destructive though moderate earthquakes generated by blind or elusive thrusts (e.g., Hauksson et al., 1988; Dolan et al., 1995; Shaw and Suppe, 1996). Given the hidden nature of these seismogenic faults and related structures, they have been traditionally explored only by means of indirect methods such as interpretation of growth strata (e.g., Suppe et al., 1992), geodesy (e.g., Lin and Stein, 1989; Massonet et al., 1993) and morphotectonic studies (e.g., Bullard and Lettis, 1993).

The aim of this work is to present a geomorphological method for the identification of blind active faults associated with subdued topographic expression. We focused on the Po Plain, a lowrelief sedimentary basin intensely deformed by 
buried folds and thrusts, as revealed by extensive oil exploration (fig. 1a,b). In spite of the occurrence of historical earthquakes up to magnitude 6.5 , the activity of individual tectonic structures is poorly known. The Po Plain is one of the most densely populated areas of Italy, has a rich patrimony of old historical towns, and represents the most important concentration of industrial facili-
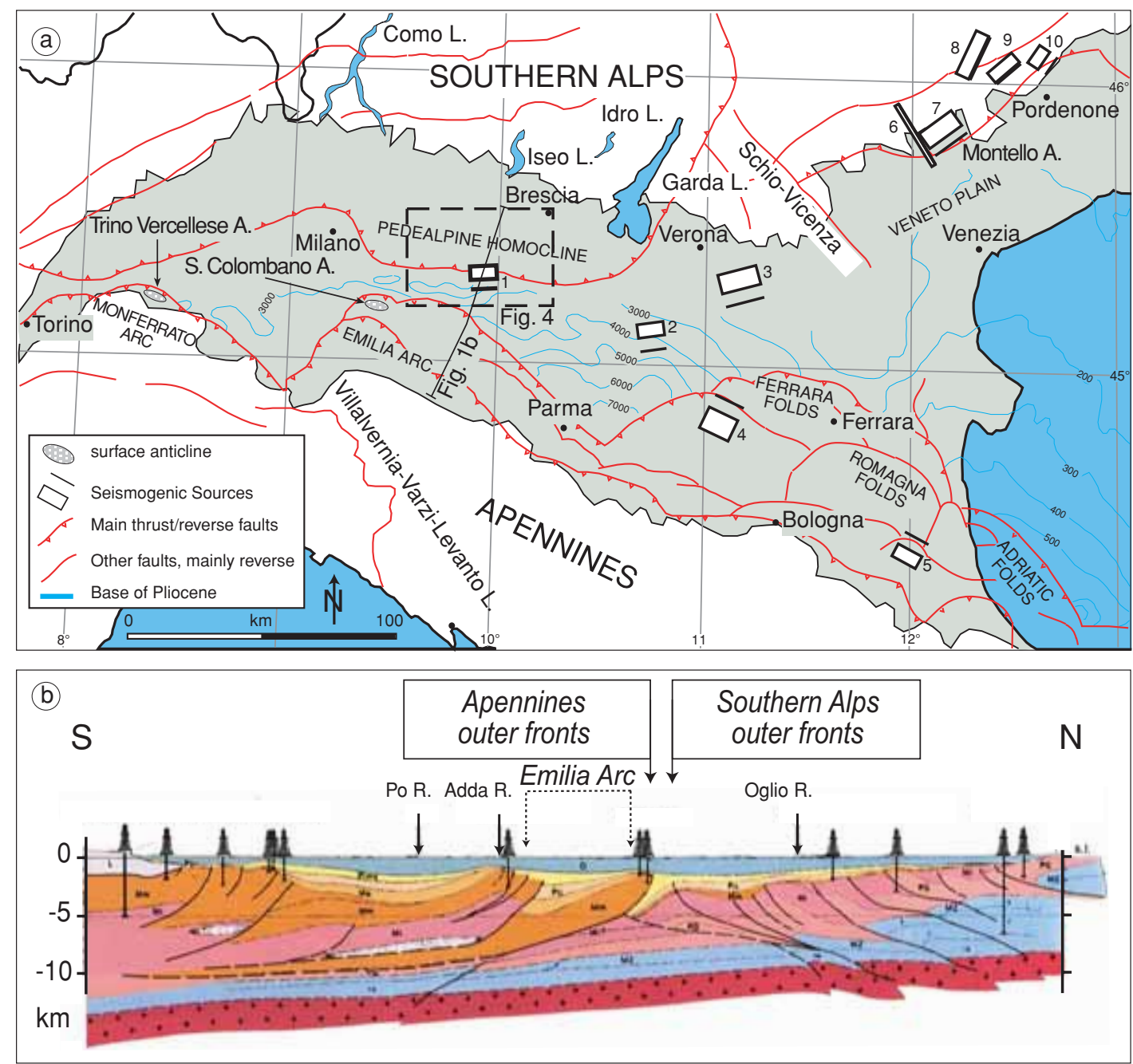

Fig. 1a,b. a) Simplified structural map of the Po Plain and neighbouring Veneto Plain, showing the main tectonic elements (from Pieri and Groppi, 1981, modified), and contours of the base of the Plio-Quaternary sedimentary sequence (from Bigi et al., 1989). The plain is shaded in light grey, while higher topography regions are shown in white. The outer thrust fronts of the Southern Alps and of the Apennines are buried beneath the thick syn-orogenic clastic deposits. The seismogenic sources are from Valensise and Pantosti (2001b) and are identified in table II. b) Structural cross-section of the Central Po Plain, showing the main buried thrust fronts of the Northern Apennines and Southern Alps (from Cassano et al., 1986, modified). Location of the trace is shown in fig. 1a. 


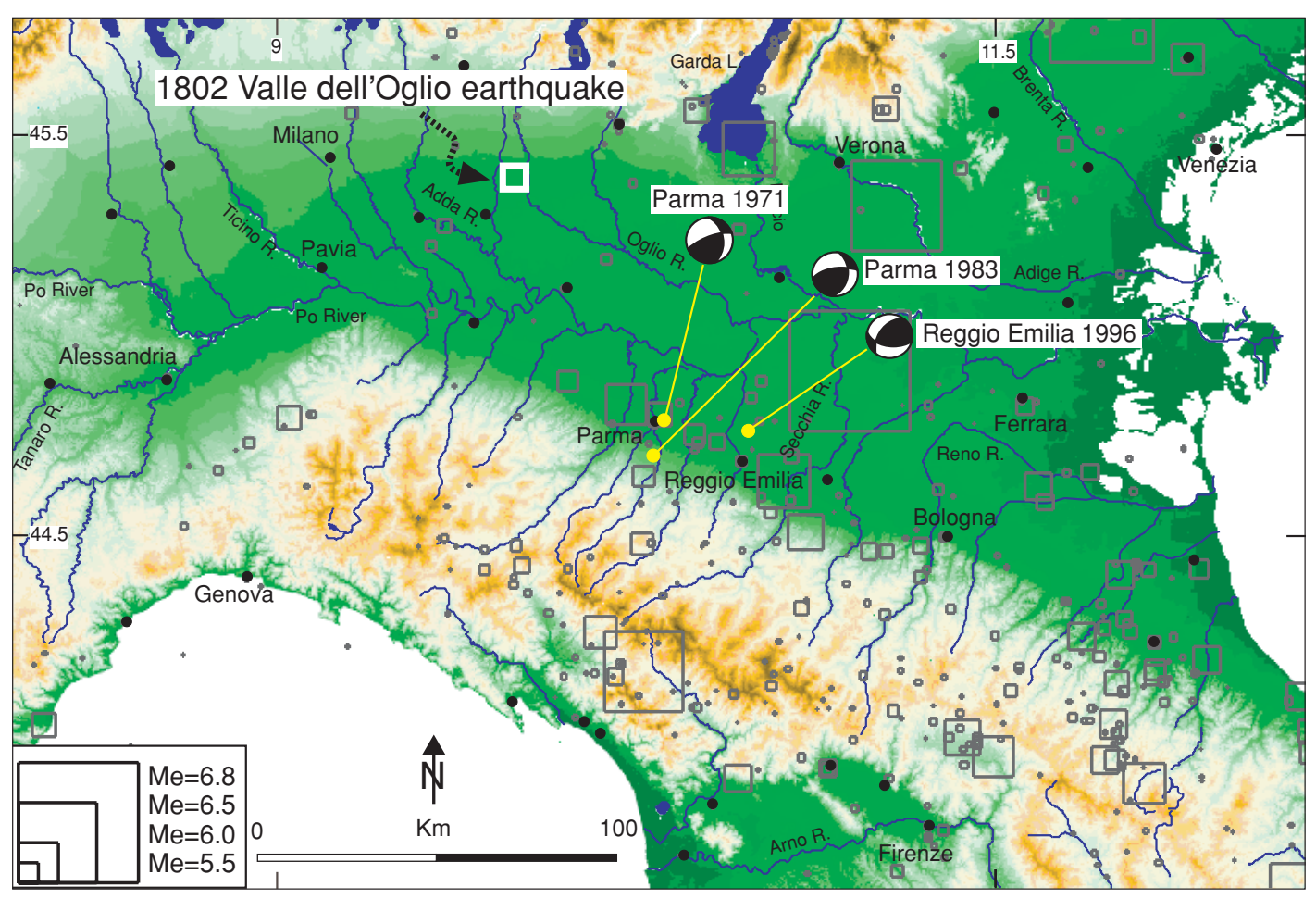

Fig. 2. Historical seismicity of the Po Plain (CPTI, Working Group, 1999). The focal mechanisms of the three largest instrumental earthquakes recorded in the area are consistent with ongoing N-S contraction. In contrast, seismicity recorded in the inner portions of the Apennines chain is mainly extensional. Only a few earthquakes are reported north of the Po River, and seismicity does not follow a regular pattern.

ties country-wide. In contrast with its high vulnerability, it is traditionally considered a region of low seismic hazard (e.g., Albarello et al., 2000). Current historical catalogues list very few large earthquakes in the area and show that most of them do not exceed $M_{e} 5.5$ (equivalent magnitude from CPTI, Working Group, 1999). Most of the seismicity is concentrated south of the Po River along the Apennine foothills and on some Apennine outer fronts (fig. 2). Conversely, the seismicity is more sporadic in time and space north of the Po River. No significant historical or instrumental earthquakes are documented west of Milan, except for a few events in the Monferrato area.

Since even moderate earthquakes can produce extensive damage due to the high exposure of buildings and facilities, the identifica- tion and characterisation of potential seismogenic sources is crucial for mitigating the seismic risk. To locate the areas undergoing tectonic vertical deformation we adopted a geomorphological approach based on the analysis of the pattern and behaviour of the fluvial network. Alluvial rivers are very sensitive to modest ground tilting, to which they react with deflections and changes of their sedimentation pattern. We believe this approach is especially promising in areas such as the Po Plain, where the evolution of the drainage pattern is not affected by morphological obstacles nor controlled by bedrock heterogeneities. Only two anticlines are associated with a morphological expression (fig. 1a,b): the Trino Vercellese Anticline (Western Po Plain), which has about 


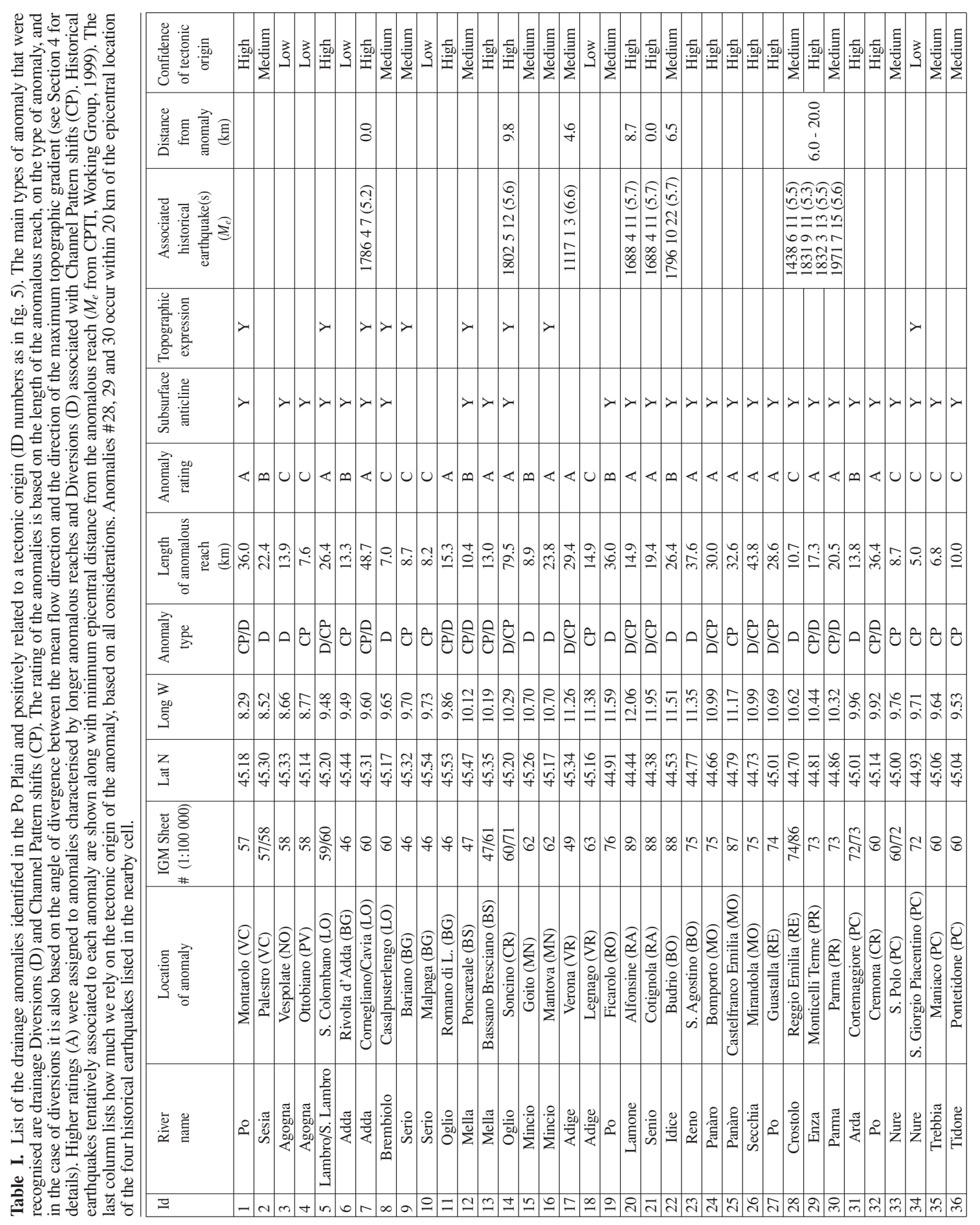


$40 \mathrm{~m}$ of relief and forces the Po River to follow an anomalous course (anomaly \#1 in table I); and the San Colombano Anticline (Central Po Plain), associated with the sharp eastward deflection of the Southern Lambro River (anomaly \#5 in table I). We used basic topographic data (topographic maps and DEM) to identify anomalous reaches along several alluvial rivers draining the Po Plain.

In general, anomalies in the drainage pattern may be ascribed to three main families of causes: climate, human activity and tectonic activity. Climate changes may induce rivers to cross critical erosional or depositional threshold values controlling major channel pattern changes (Schumm and Khan, 1972). Human activities may induce changes in the fluvial system by direct modifications of the channel (e.g., engineering works and drainage regulation), by indirect alteration of the stream discharge and sediment load transport (Knighton, 1984), or by modifying the stream gradient through ground-water withdrawal. Tectonic activity produces longitudinal and lateral changes of the stream gradient, that alone may induce channel pattern shifts and diversions. These tectonic modifications, however, may accumulate and become apparent only in conjunction with extreme climatic events altering water discharge and sediment supply.

The anomalies we identified consist in river diversions, shifts in channel pattern and longitudinal changes of the channel behaviour. Due to their size, they are suggestive of the presence of active buried tectonic structures. Their true origin was assessed by spatial comparison between their location and the pattern of buried anticlines reported in the geological maps, and with the historical earthquakes listed in current catalogues.

We constructed a database of 36 anomalous reaches along more than 20 rivers. Each anomaly is believed to be evidence of the activity of a blind thrust (table I). We could discriminate the seismic versus aseismic behaviour of the underlying fault only for a few cases where the anomaly is unambiguously associated with historical or instrumental seismicity.

We present as a case history the application of this approach to the identification of the source of the 12 May 1802 earthquake $\left(M_{e} 5.7\right)$, that struck the Oglio River Valley near Soncino (Cremona).

\section{Geologic and geomorphic overview of the Po Plain}

\subsection{Tectonic setting}

The geologic evolution of the Po Plain reflects the regional convergence between the African and European plates. This sedimentary basin is located at the northern termination of the Adria microplate, a promontory of the African plate. Since Late Cretaceous it represented the foreland of two chains of opposite vergence generated by the collision between the African and European plates (e.g., Robertson and Grasso, 1995): the north-verging Apennines and the south-verging Southern Alps. Thrusting of these two chains loaded and flexed the Adria continental crust, giving rise to foredeep basins where a thick syn-orogenic clastic sequence was deposited (Doglioni, 1993, and references therein). As suggested by plate motion reconstructions (DeMets et al., 1994), and confirmed by seismicity (CPTI, Working Group, 1999) relative motion between the two plates is ongoing with a convergence in a NNW-SSE direction, that geodesy indicate to have a rate of less than $1 \mathrm{~cm} / \mathrm{yr}$ (Ward, 1994; Anzidei et al., 2001). Part of this deformation is accommodated seismically within the thrust fronts of the two chains.

Due to the fast subsidence rates induced in the whole Po Plain area by the tectonic loading of the two chains, the more external fronts of the two thrust belts are buried beneath the plain. Therefore the main tectonic elements were mapped by means of the extensive seismic reflection data used for oil exploration (Pieri and Groppi, 1981). The map of the base of the Plio-Quaternary sequence south of the Po River (Pieri and Groppi, 1981) shows the occurrence of three arcs of blind, north-verging thrusts and folds that define the Apennine thrust fronts (fig. 1a,b), from west to east: a) the Monferrato Arc (Elter and Pertusati, 1973); b) the Emilia Arc, and c) the Ferrara-Romagna Arc. The latter is further subdivided into three relatively minor structures: the Ferrara folds, the 
Romagna folds and the Adriatic folds. The Ferrara folds («Dorsale Ferrarese») are the most external structures of this arc. North of the Po River, the outer fronts of the Southern Alps thrust belt are arranged in a more simple pattern and deform the south-sloping Pedealpine homocline (fig. 1a). The E-W continuity of the thrust front is interrupted by the Schio-Vicenza Line, an important transfer structure that separates the Po Plain thrust fronts to the west, from those of the Veneto Plain, to the east. In spite of the diffuse folding and thrusting imaged in the subsurface of the Po Plain by the geophysical exploration, very few tectonic structures are expressed at the surface. The most noticeable exceptions are represented by the Trino Vercellese Anticline, the San Colombano Anticline and the Montello Anticline in the Veneto Plain (from west to east, fig. 1a). The Quaternary activity of these structures is testified by their influence on the drainage pattern and by the presence of young terraced surfaces tilted and uplifted along their flanks (Ferrarese et al., 1998; Benedetti et al., 2000; Castiglioni and Pellegrini, 2001).

During the Tertiary and the Quaternary, a considerable thickness of sediments was deposited in the Po Valley Basin, on top of a sequence of Mesozoic passive margin carbonatic rocks. As a whole this clastic sequence is a regressive succession. Sediment sources included the Southern Alps and Apennines fold and thrust belts. On the southern side of the Po Plain, the Plio-Quaternary sediments in the foredeep are 7-8.5 km thick (Doglioni, 1993). Sediments in the Southern Alps foredeep, are between 2 and $6 \mathrm{~km}$ thick (Doglioni, 1993; Bertotti et al., 1998).

\subsection{Seismicity}

Most of the earthquakes listed in current historical catalogues are concentrated south of the Po River along portions of the pede-Apennines thrust front and on some buried Apennines outer fronts. Earthquakes are more infrequent north of the Po River and west of Milan, where only background micro-seismicity is recorded (fig. 2).
The most recent large earthquakes of the region occurred in 1971 and 1983 near Parma ( $M_{s} 5.7$ and 5.0, respectively), and in 1996 near Reggio Emilia $\left(M_{s} 5.1\right)$. The focal mechanism of the 1971 Parma event shows a reverse solution with a large strike-slip component (Anderson and Jackson, 1987). The Centroid Moment Tensor solutions of the 1983 Parma and 1996 Reggio Emilia events (CMT Harvard Catalogue, Dziewonski et al., 1983) show a thrust solution with a small strike-slip component, and with $P$-axis oriented $\mathrm{N} 36^{\circ} \mathrm{W}$ and $\mathrm{N} 24^{\circ} \mathrm{W}$, respectively. This compressional tectonic regime is confirmed by the analysis of the Reggio Emilia main shock and related aftershocks (Selvaggi et al., 2001). The focal mechanisms are consistent with a N-S sub-horizontal $\sigma_{1}$. Similar results were reached by Frepoli and Amato (1997), who obtained N-S oriented compressional $P$-axes using fault plane solutions, and Montone and Mariucci (1999) with an analysis of borehole breakouts, that show $S_{H \max }$ oriented perpendicular to the trend of the thrust fronts. Other recent instrumental earthquakes include the 2000 Reggio Emilia event $\left(M_{w}\right.$ 4.5), the 2000 Faenza-Forlí sequence ( $M_{w}$ 3.4-4.4), and the 2000 Monferrato event $\left(M_{w} 4.6\right)$.

\subsection{Geomorphology}

The Po Plain stretches E-W across northern Italy for more than $40000 \mathrm{~km}^{2}$, and is the widest alluvial basin of the peninsula. It is delimited both south and north by the topographic highs of the Apennines and of the Alps, respectively, and to the east by the Adriatic coastline. The plain is locally up to $100 \mathrm{~km}$ wide, and is drained axially by the $652 \mathrm{~km}$ long Po River. For most of its course the Po is an alluvial river characterised by a single meandering channel. Its catchment basin is larger than $70000 \mathrm{~km}^{2}$.

The Po Plain can be separated into several Quaternary geomorphological units (MURST, 1997a; Marchetti, 2002, and references therein). The area located between the southern boundary of the Alps and the Po River is characterised by the presence of a wide low-gradi- 
ent, south-sloping depositional surface of fluvio-glacial and fluvial origin. This outwash plain, locally named «Plain main level» (Livello fondamentale della pianura in Petrucci and Tagliavini, 1969), was built up during the last glaciation, when rivers flowing from the Alps were characterised by water discharge and sediment supply substantially larger than today (Marchetti, 1990, 1996). Abandoned paleo-channels seen on top of this surface are oversized with respect to the present hydrography, implying a change in discharge occurred at the end of the last glaciation which led to the erosion of the alluvial plain (Marchetti, 1996). The present drainage network flows in valleys deeply incised into the aggradation surface. Small patches of early to Middle Pleistocene fluvioglacial deposits («old terrace unit», Marchetti 2002), and moraine deposits of PleistoceneHolocene age, near the outlets of the main alpine valleys, border the Po Plain at the Alps foothills. South of the Po River the drainage network flows on top of a Holocene aggradation surface, which merges with the active alluvial plain of the axial Po River. Continuous sedimentation is suggested by buried archaeological artefacts ranging in age from the Neolithic period to the Middle Ages (Marchetti, 2002). Close to the Apennine margin this surface is covered by coalesced alluvial fans of the same age as the «Plain main level», overlain by older fans deposited during previous glacial maximums (Marchetti, 2002 and reference therein). In contrast with the rivers flowing from the Alps, the Po River and its right tributaries flow on top of an active alluvial plain.

\section{Geomorphic indicators of growing anticlines}

Growing anticlines and tilting over a wide region encompassing an anticline-syncline pair are the surface expressions of slip on an underlying buried thrust or reverse fault (e.g., Yeats, 1986; Stein and Yeats, 1989) (fig. 3). There are numerous geological, geomorphic and landscape features that are sensitive to slip on a buried thrust fault: topography, the thickness and shape of growth strata, the erosional/depo-

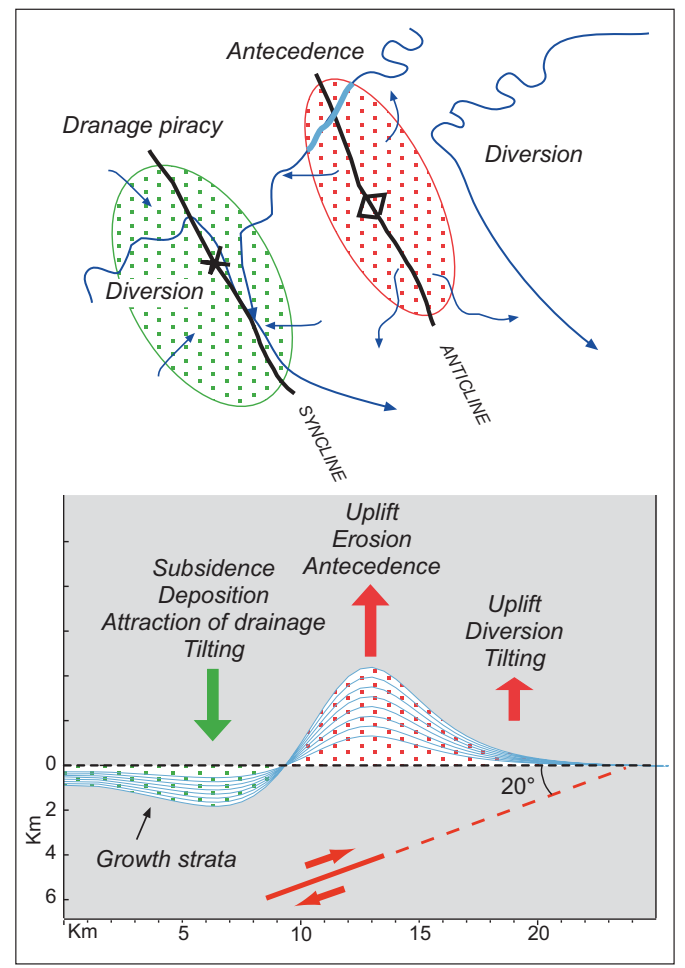

Fig. 3. Schematic representation in map view (above) and cross-section (below) of the effects that slip on a generic blind, low-angle thrust fault may have on geomorphic/sedimentary processes. The vertical component of the expected deformation is related to the fault's geometry and kinematics through the elastic dislocation theory. Evolution of sedimentation and drainage pattern over a wide area is controlled by the growth of the anticline/syncline, which produces tilting of the ground surface.

sitional behaviour of the drainage network, and the geometry of any erosional and/or depositional surfaces. The drainage network is especially sensitive to vertical deformation and thus very useful for analysing low-relief areas, where few or no landforms constrain the location of active faults (Holbrook and Schumm, 1999; Schumm et al., 2000). Field studies and numerical models show that the interaction between drainage systems and tectonic sources is governed mainly by the geometry and kinematics of the tectonic source (e.g., Champel et al., 2002) and by 
the relative size of the rivers (e.g., Guccione et al., 2002). Fault characteristics control the pattern and style of surface deformation, whereas the capacity of the rivers to keep pace with the uplift relies on their size (see for example the longitudinal stream profiles in Burnett and Schumm, 1983).

The fault-induced permanent deformation of the Earth surface controls the drainage pattern and the associated geomorphic/sedimentary processes. In particular the uplifted area is subjected to erosion, lack of drainage and antecedence phenomena, while the subsiding area is subjected to attraction of drainage and deposition (fig. 3). River diversions are the most clear indicators that the stream is approaching a rising anticline or entering a syncline. The evolution of sedimentation and topography and of the geometry of geomorphic features is controlled by the growth of the anticline and of the syncline, which may or may not have a perceptible morphologic expression depending on the ratio between tectonic and sedimentation rates. More specifically, if the rate of vertical tectonic displacement is higher than the sedimentation rate, the anticline will have a morphological expression and will be subjected to erosion, while the syncline will be represented by a depressed area that may be filled up with sediments. The evolution of the tectonic topography created by the growth and lateral propagation of the anticline is controlled by linear and areal surface processes that tend to create a smoothed steadystate morphology (Champel et al., 2002).

When a river enters a zone of active subsidence or uplift it may change its graded longitudinal profile. The river may then cross the zone undergoing deformation, or be deflected by it (Holbrook and Schumm, 1999). The river incises the area of steepened gradients over the growing structure and aggrades where the slope again decreases downstream. Similarly, the increase or decrease in slope caused by an impeding zone of uplift or subsidence may alter the channel pattern of a river (braided, meandering or anastomosing) and its stream power. Variations of the stream power have a direct effect on the grain size of the stream bedload. In general, tectonically increased slopes will be characterised by increased bedload grain size, and vice versa (Ouchi, 1985). Deflection of the river around an area undergoing uplift or subsidence will appear as an abrupt shift in the river course coincident with the deformed zone (Holbrook and Schumm, 1999).

In addition to the deformation seen in a longitudinal profile, tectonic activity may also produce lateral shifting of a river (normal to the topographic gradient of the floodplain). Shifting may occur by sudden avulsion or slow migration (combing) of a stream toward the lower down-tilt part of the floodplain depending on the rate of lateral tilt (Peakall et al., 2000).

Schumm and Khan (1972) performed a series of experiments in a large flume to determine the effect of changing slope and sediment load on channel patterns. These experiments suggest that sediment loads and slopes are closely related, and that landforms may not always respond progressively to altered conditions. Rather, dramatic morphologic changes may occur abruptly when critical erosional and (or) depositional threshold values are exceeded.

All of the above effects may be recorded in the alluvial stratigraphic sequence, and their detailed study allows areas of persistent anomalies to be located and characterised. Unfortunately, such anomalies may also arise from non-tectonic processes that induce variations of the topographic gradient. For this reason, ruling out other explanations for the observed anomalies is important before they can be confidently interpreted as indicators of tectonic activity (Holbrook and Schumm, 1999).

\section{The case of the Po Plain: river anomalies versus subsurface data and seismicity}

Very few anticlines in the Po Plain have a surface expression, probably because sedimentary rates outpace tectonic rates. For example, Vittori and Ventura (1995) proposed Late Pleistocene-Holocene sedimentation rates of $0.6-2.1 \mathrm{~mm} / \mathrm{yr}$ for the central part of the basin. These estimates compare with preliminary slip and vertical displacement rates of 1.7 and 0.6 $\mathrm{mm} / \mathrm{yr}$, respectively for the fault driving the Mirandola anticline, one of the fastest growing 
structures of the entire Po Plain (Ciucci et al., 2002; shown as n. 4 in fig. 1a). The Geomorphological Map of the Po Plain (MURST, 1997a) shows numerous examples of drainage diversion which in some cases have been dated by radiometric and archaeological methods. This geomorphological record extends back in time to the beginning of the Holocene at the earliest, when morphogenic processes triggered by the last glacial maximum formed the «Plain main level» on the northern side of the Po Plain and started continuous fluvial aggradation on its southern side (Marchetti, 2002). In this context, several rivers show an evolution of their pattern that is not random, but rather seems to be driven by long-lasting vertical motions that resemble the surface effects induced by the activity of blind thrusts. A striking example is given by the Po River just south of Mantova, whose course has been shifted northward possibly due to the activity of the Ferrara folds, as suggested by the abandoned paleochannels south of its present position.

We analysed systematically the response of drainage to the tilt induced by folding. The drainage response varies in trend and strength depending on the location of each given stream section relative to the fault. To reproduce the indications arising from the geomorphological analysis, which constrain the location of the anticline/syncline couple, we use elastic dislocation modelling. Our approach assumes permanent deformation of an essentially unfractured uppermost portion of the crust, such that the direction and magnitude of tilting can be derived from the fault parameters via elastic dislocation theory. Our starting assumption is that where folds are not expressed at the surface and a thick alluvial bed isolates the drainage network from the fold, rivers should generally flow in the direction of the maximum topographic gradient. Regional topography of the Po Plain is indicated by contour lines that open eastward toward the Adriatic coastline, and by a central trough occupied by the Po River (see the colour coded topography in fig. 2). This pattern is the compounded result of regional uplift of the Northern Apennines (along a NW-SE axis) and Southern Alps (along a roughly E-W axis), infilling of the basin and subsequent eastward regression of the coastline. Local modifications of the regional slope are highlighted by drainage anomalies of the same wavelength: drainage in subsiding areas is marked by low slope and aggradation, whereas in uplifting zones by increased gradient and incision.

We adopted a quantitative method to locate areas undergoing local differential vertical motions, based on the detailed analysis of the topography and of the drainage network. To perform this analysis we used official topographic maps (IGMI, scale of 1:25000), the regional Map of Relief and Vertical Movements of the Po Plain (scale 1:250000) (MURST, 1997b), and digital elevation models with the resolution of $230 \mathrm{~m}$.

The methodology used to determine the presence of an anomaly in the flowing direction of the drainage network is shown in fig. 4. It consists in determining the average contour strike of the surface of the Plain main level (the depositional surface before the last deglaciation), with tangential segments along each contour line. The tangentials were taken at the down-slope convexities of the contour lines to reproduce with a maximum accuracy the preerosional surface. Maximum topographic gradient (red vectors in fig. 4) represents the direction orthogonal to these tangential lines, and we assume that drainage should flow in this direction. We then compared the flow direction of each river between the contour lines (dashed blue vectors in fig. 4), with the topographic gradients. We conventionally declared a drainage anomaly any time we found a divergence $\geq 10^{\circ}$ between these two vectors. We also considered the length of the reach over which the divergence persisted, adjusted to the river size. This is important to avoid sampling natural irregularities (such as large meanders) as anomalous reaches, and also because we expect that the size of the tectonically driven anomalies is related to the size of the underlying hidden fault. We declared an anomalous reach only if the divergence between the two vectors persisted for more than $5 \mathrm{~km}$. This minimum length was chosen considering the average length of the longer meanders measured in the area. Besides being more easily detectable, larger anomalies imply bigger faults that may pose the largest hazard. For some rivers along which we identified such diversions, we searched for 


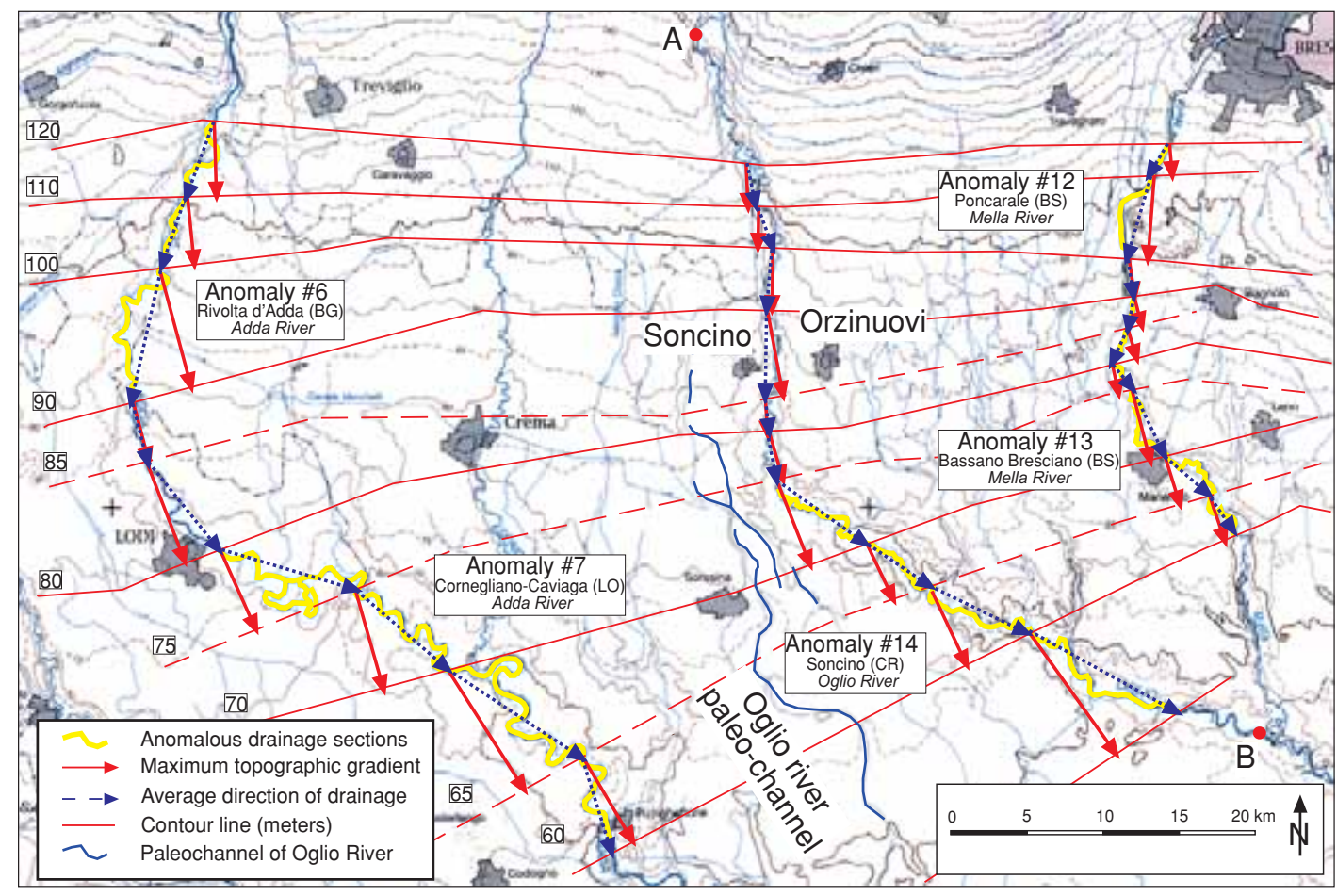

Fig. 4. Outline of the method used to detect drainage anomalies in the Po Plain. The figure shows an area located north of the Po River, between the Adda River and the Mella River. Straight-line segments at contour line intervals ranging between 5 and $10 \mathrm{~m}$ were constructed from the Map of Relief and Vertical Movements of the Po Plain (MURST, 1997b). Solid red arrows and dashed blue arrows show topographic gradients and actual average drainage directions, respectively. We defined a drainage anomaly as $\mathrm{a} \geq 10^{\circ}$ divergence between the two vectors. Anomaly \#14 on the Oglio River is analysed in detail. A and B mark the ends of profiles shown in fig. 7.

channel pattern shifts, using topographic maps and air photos interpretation.

We then removed all anomalies possibly correlated with human activity (artificial deviations, significant fluid withdrawal, etc.) or for which a tectonic origin can be easily ruled out, using ancient topographic maps and historical accounts. The remaining anomalies are listed in table I, that summarises their main features and possible association with historical earthquakes.

Geological maps (1:100000 scale) were used to compare spatially the anomalies with the position of structural axes, buried faults and lithological contacts. This step allowed us to correlate a- nomalies with buried tectonic structures. A further spatial comparison was made with the historical earthquakes listed in the Catalogo Parametrico dei Terremoti Italiani (CPTI, Working Group, 1999). This second step suggested that the activity of at least some of the structures is potentially seismogenic. The observation of seismicity associated with a given anomaly supports the hypothesis of its tectonic origin.

Some of the areas where the above correlations appear to be most meaningful are shown in fig. 5. Areas outlined by black dotted circles exhibit strong correlation between drainage anomalies and buried anticlines (indicated with $\mathrm{A}$ and $\mathrm{B}$, respectively). Areas indicated with A 


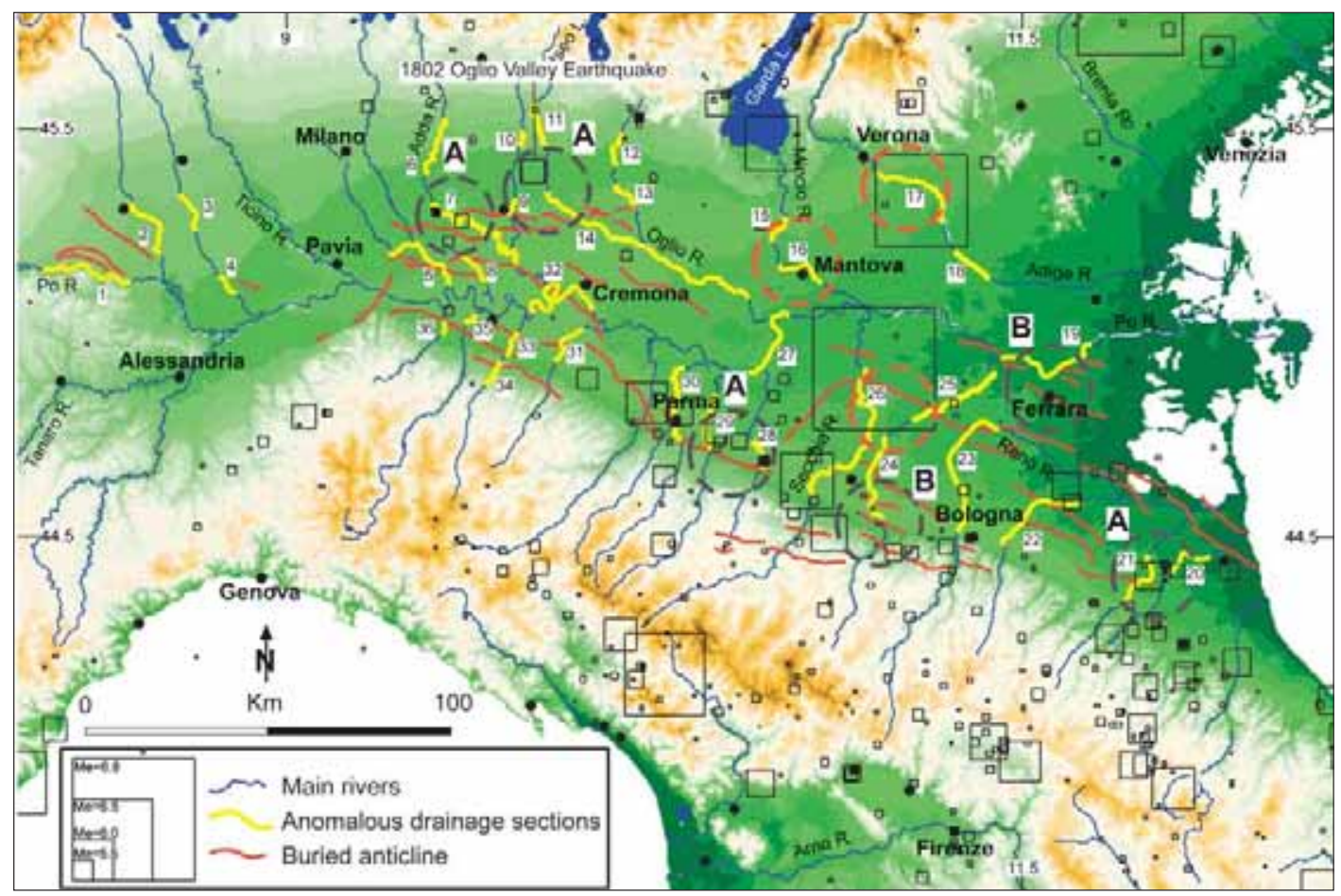

Fig. 5. Distribution of drainage anomalies in the Po Plain (marked in yellow). Dashed black circles labelled A outline areas where an anomaly, a fold axis, and a historical earthquake coincide. Dashed black circles labelled $\mathrm{B}$ indicate areas where surface evidence corresponds to buried anticlines, but no historical earthquakes are reported. Dashed red circles highlight areas that require further investigations: see text for discussion. Drainage anomalies are numbered according to table 1.

also exhibit some correspondence with historical seismicity. Areas shown as red dotted circles do not show any clear correlation and hence require further investigations. This is the case of Mantova (Mincio River, anomaly \# 16), where a clear topographic and drainage anomaly is not related to any known structural element nor to historical earthquakes. In the area between the Secchia and Panaro rivers, the anomalies (\#24 and \#26, fig. 5) are positively related with known large subsurface structures but there is no report of significant earthquakes. In the case of Verona (Adige River) the observed anomaly, can not be correlated to any known buried anticline, although it may be associated to slip on the fault respon- sible of the large 1117 earthquake $\left(M_{e}\right.$ 6.6; CPTI, Working Group, 1999).

\section{A case history: anomalies of the Oglio River and the 1802 earthquake}

The anomaly under examination (\# 14, table I and fig. 5) is represented by an abrupt southeastward turn of the Oglio River south of Soncino and Orzinuovi, towns located $35 \mathrm{~km}$ to NW of Cremona (figs. 4 and 5). A paleochannel located south of the anomaly suggests a structural control on the river evolution (fig. 4). This section of the Oglio River exhibits anomalies both in terms of trend (SW diversion) and overall behaviour (increase of 
erosion power and sinuosity). These observations may all be explained with the presence of an area undergoing relative uplift affecting the river bed, and located south of the diversion.

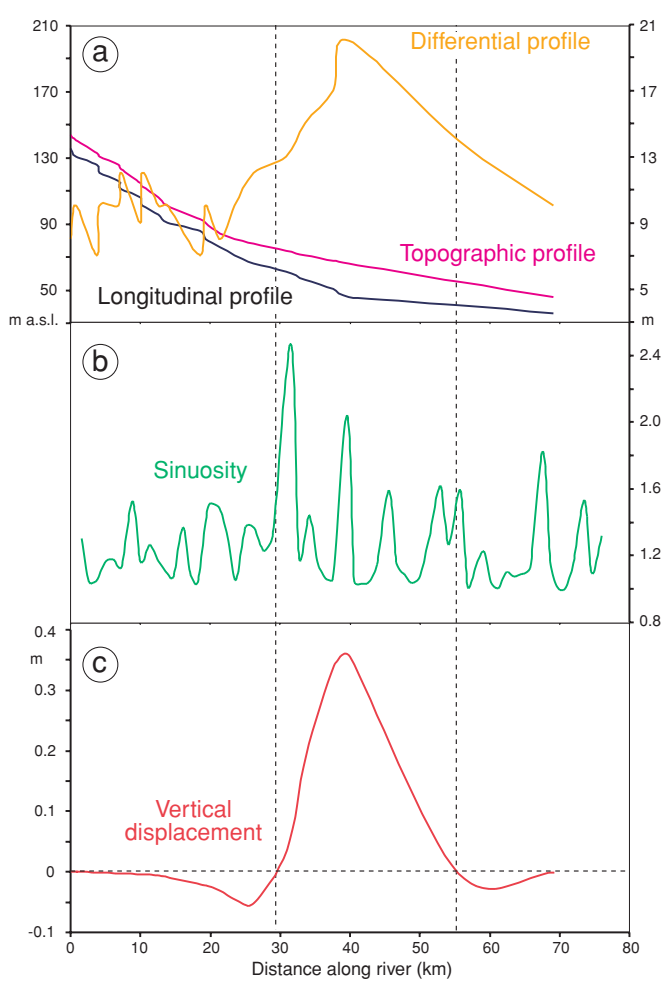

Fig. 6a-c. Profiles of the Oglio River from the Alpine frontal moraines to the confluence with the Mella River. a) The differential profile, obtained by subtracting the elevation of the river bed from the average elevation of the Plain main level, shows a dramatic increase of incision in the distance range $30-50 \mathrm{~km}$, suggesting that the river meets an area of localised uplift. b) An increment of sinuosity highlighted at about $30 \mathrm{~km}$ from the upper-end of the section is possibly related to a variation of the longitudinal slope of the river bed. c) Expected vertical displacement along the river bed generated by slip on a blind, $30^{\circ}$-north dipping thrust fault (full faulting parameters and location of the modelled fault shown in fig. 8 and table II). This fault explains the geomorphic observations (longitudinal anomalies of the Oglio River as well as its SE-diversion) and fits subsurface geological data (see upper-left inset of fig. 7). We suggest that this fault is the causative source of the 1802 earthquake.
To explore the longitudinal behaviour of the Oglio River we used a set of three different types of profiles (fig. 6a-c): a longitudinal profile of the river bed, a topographic profile of the river banks, and a differential profile (difference between the previous two profiles). The differential profile was calculated to highlight the possible existence of reaches along which the river is actively eroding its bed, as a consequence of localised uplift. The first two profiles show that the river flows in a valley incised into the Plain main level by about $10 \mathrm{~m}$ (fig. 6a), whereas the third profile highlights that the differential relief reaches a maximum in the distance range 30-55 $\mathrm{km}$, where relative uplift is inferred to be greatest. Most of the valley incision occurred at the end of the last glaciation, and it was the result of changes of water discharge and sediment supply. The two reaches up-stream and down-stream of the diversion are characterised by rather different longitudinal gradients, the higher being along the first reach. Instead, the topographic profile along the stream banks shows that there is a change in slope at about down-stream distance $20 \mathrm{~km}$, that may correlate with the toe of the alluvial fan of the Oglio River. Up-stream of this point the profile is parallel to that of the river bed, indicating uniform erosion along this reach. We interpret the increase of the trend of the differential profile between distance range 30-55 $\mathrm{km}$, as the result of localised uplift due to the growth of a buried anticline (fig. 6c). An additional indication comes from the longitudinal sinuosity profile (fig. $6 \mathrm{~b}$ ), which shows an increment at the beginning of the section characterised by the increase of relief, indicated by the presence of two peaks of high sinuosity. Sinuosity was calculated as the ratio between the true $\left(d_{t}\right)$ and straightened $\left(d_{s}\right)$ distance covered by the river along a given stretch, averaged over a distance of about $1 \mathrm{~km}$

$$
\text { Sinuosity Index }=d_{t} / d_{s} \text {. }
$$

We interpret the two peaks of high sinuosity as a shortening of the wavelength of the meanders due to an obstacle to their down-stream migration.

A strong earthquake $\left(M_{e}\right.$ 5.7) occurred on 12 May 1802 in the Oglio Valley, the flat area 


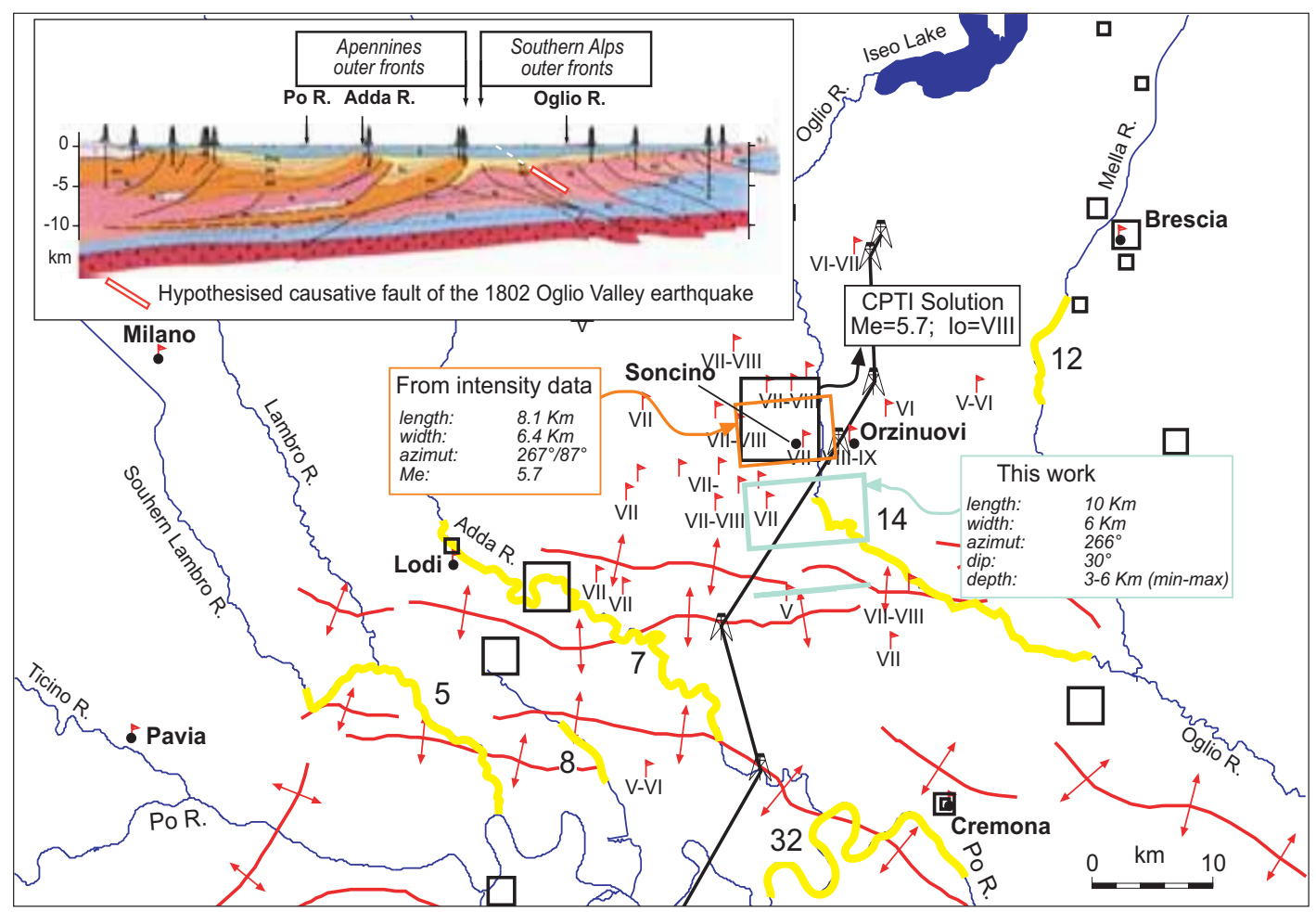

Fig. 7. Intensity data for the 12 May 1802, $M_{e} 5.7$ earthquake (Boschi et al., 2000), the Oglio River anomaly (\#14), and buried anticlinal axes from geological maps. Two fault models respectively obtained from intensity data (using the Boxer code, Gasperini et al., 1999) and geomorphological observations (this work) are shown for comparison. The black line is the trace of the geological section obtained from geophysical data shown in the upper left corner (from Cassano et al., 1986, modified). It shows that in this area the south-verging Alpine front faces the north-verging Apennine outermost fronts. We propose that the seismogenic source of the 1802 earthquake is a south-verging blind thrust fault belonging to the alpine system.

between Brescia and Cremona near Soncino (fig. 7). Over twenty towns were severely damaged, including Soncino, Crema, Brescia and Cremona, and among those Orzinuovi was the most seriously hit.

A solution obtained through the automatic elaboration of macroseismic intensity data using the Boxer code (Gasperini et al., 1999) yielded a hypothetical seismic source (fig. 7). This solution is in good agreement with indications supplied by subsurface geology, particularly as far as the orientation of the seismogenic structure is concerned. E-W buried anticlines belonging to the
Alpine domain are commonly reported just south of a major drainage anomaly of the Oglio River (\#14 in table I and fig. 5), which starts near Soncino and continues southward for approximately $25 \mathrm{~km}$. A geological section obtained from geophysical data (Cassano et al., 1986; inset in upper left corner of fig. 7) clearly shows the south-verging alpine fronts which, near Cremona, face the north-verging thrusts of the Apennines domain.

Assuming that the above geomorphological observations can be explained by the activity of the causative fault of the 1802 earthquake, we calculated the expected displacement for uni- 
Table II. Parameters of the seismogenic sources of the Po and Veneto plains included in the Database of Potential Sources for Earthquakes larger than M 5.5 in Italy (Valensise and Pantosti, 2001b). Each source is keyed to fig. 1a,b through a code. The Orzinuovi seismogenic source (\#1) is related to the 12 May 1802 Oglio Valley earthquake, and was identified through the geomorphological approach presented in this work. Its geometrical and kinematic parameters were used for the dislocation modelling (see fig. 8).

\begin{tabular}{ccccccccc}
\hline \hline$\#$ & Source Name & $\begin{array}{c}\text { Length } \\
\mathrm{km}\end{array}$ & $\begin{array}{c}\text { Width } \\
\mathrm{km}\end{array}$ & Strike & Dip & Rake & $\begin{array}{c}\text { Min depth } \\
\mathrm{km}\end{array}$ & $\begin{array}{c}\text { Max depth } \\
\mathrm{km}\end{array}$ \\
\hline 1 & Orzinuovi & 10.0 & 6.0 & $266^{\circ}$ & $30^{\circ}$ & $90^{\circ}$ & 3.0 & 6.0 \\
2 & Mantova & 10.0 & 6.0 & $262^{\circ}$ & $30^{\circ}$ & $90^{\circ}$ & 3.0 & 6.0 \\
3 & Adige Plain & 15.0 & 8.5 & $255^{\circ}$ & $30^{\circ}$ & $90^{\circ}$ & 3.0 & 7.3 \\
4 & Mirandola & 12.0 & 10.0 & $115^{\circ}$ & $30^{\circ}$ & $90^{\circ}$ & 3.0 & 8.0 \\
5 & Bagnacavallo & 10.0 & 6.0 & $119^{\circ}$ & $30^{\circ}$ & $90^{\circ}$ & 3.0 & 6.0 \\
6 & Asolo & 27.0 & 9.0 & $149^{\circ}$ & $80^{\circ}$ & $170^{\circ}$ & 1.0 & 9.9 \\
7 & Montello & 15.0 & 8.0 & $234^{\circ}$ & $30^{\circ}$ & $90^{\circ}$ & 2.0 & 6.0 \\
8 & Alpago & 18.0 & 9.0 & $206^{\circ}$ & $55^{\circ}$ & $50^{\circ}$ & 1.0 & 8.4 \\
9 & Cansiglio & 12.0 & 7.3 & $230^{\circ}$ & $50^{\circ}$ & $64^{\circ}$ & 1.0 & 6.6 \\
10 & Pordenone N. & 8.0 & 5.5 & $215^{\circ}$ & $30^{\circ}$ & $80^{\circ}$ & 2.0 & 4.8 \\
\hline
\end{tabular}

tary slip on a south-verging, $30^{\circ}$-north dipping, blind thrust fault, extending from 3 to $6 \mathrm{~km}$ of depth (table II). The vertical displacement that is expected to be generated by slip on such fault is shown in fig. $6 \mathrm{c}$ and 8.

The size of the modelled fault is upper bounded by the magnitude of the 1802 earthquake, while its exact position is constrained by geomorphological observations along the Oglio River. We changed progressively the position of the modelled fault until the maximum of relative uplift (anticlinal axis) coincided with the maximum of the differential profile, and could explain the trend of the river itself and the presence of a paleochannel south of the divergence. Fault strike was constrained based on the average strike of the buried structures reported in the literature. The contours of the expected displacement of the fault model show an anticlinal uplift south of the diversion, and only slight subsidence north of it (fig. 8). Simple scaling relationships suggest that coseismic slip in 1802 was less than $0.5 \mathrm{~m}$, yielding maximum surface vertical displacements of about $0.15 \mathrm{~m}$.

Our understanding is that, after running into an anticline which slows down its natural course, the Oglio River was forced to leave the paleochannel and turn to the ESE. This diver- sion presumably occurred before the incision of the Plain main level started, because the reach down-stream the diversion is incised and the trace of the abandoned paleo-channel is on top of this surface. The extent of the diversion represents a balance between the stream power and the uplift rate of the anticline. The seismogenic sources inferred from macroseismic intensity data and geomorphic data do not completely overlap. The macroseismic source may have been influenced by the overestimation of intensity due to the structural weakness of buildings near Soncino at the time of the earthquake, as reported in Catalogue of Strong Italian Earthquakes, 461 B.C. to 1997 (Boschi et al., 2000), or by an incomplete distribution of the data set.

\section{Discussion and conclusions}

The morphological analysis carried out in this work revealed the occurrence of several anomalies of the drainage network in the Po Plain consisting mainly in river diversions. Changes in the channel pattern were highlighted in the few areas studied in better detail. To investigate their origin we compared their position and extent with the location of buried anti- 


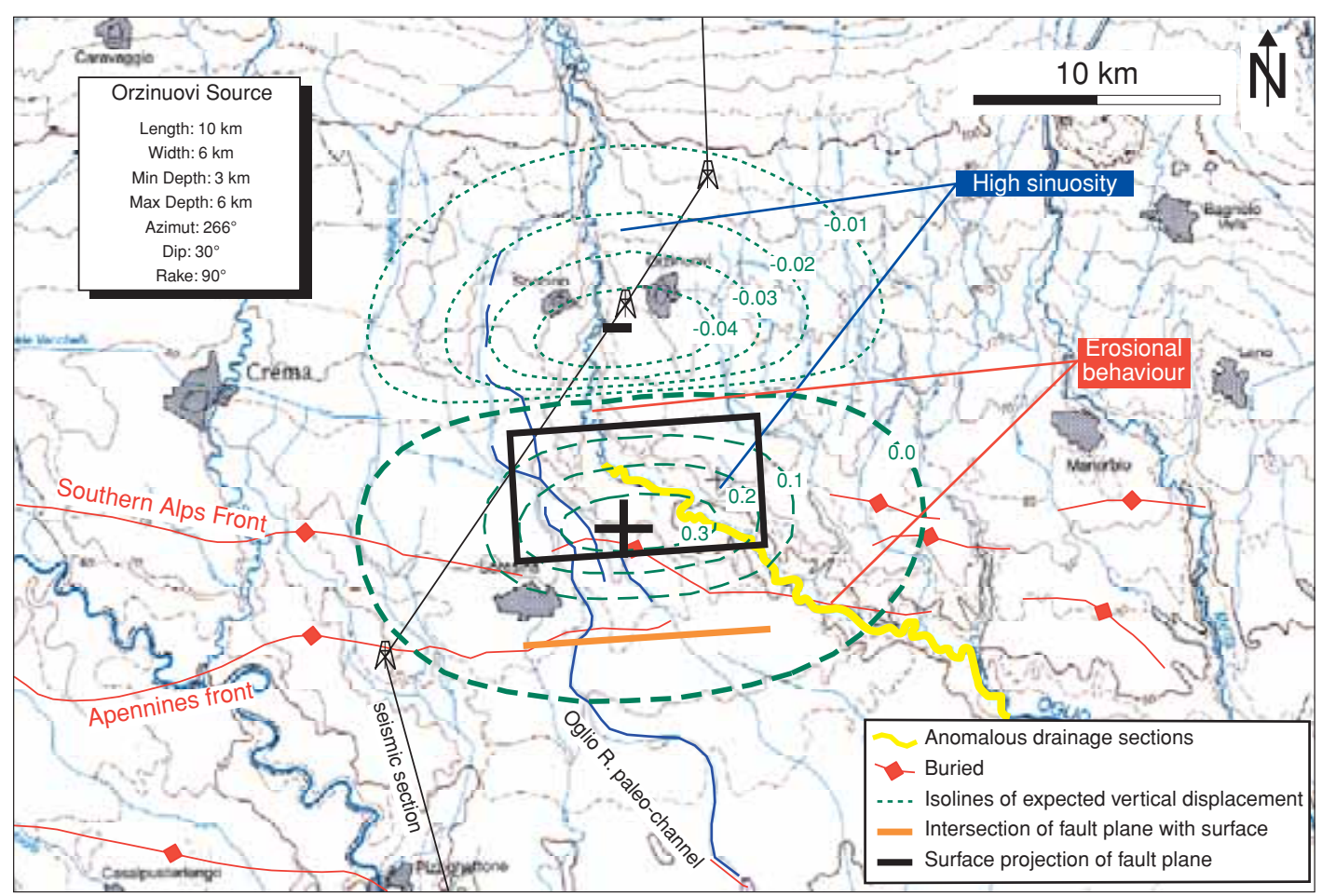

Fig. 8. Summary map showing the position of the proposed causative fault of the 12 May 1802 earthquake, contours of the expected vertical displacement and comparison with the geomorphic observations. Since this is a qualitative test of fault activity, all displacements are referred to unitary slip. Due to the lack of reliable strain and chronological markers, we did not attempt to estimate true cumulative slip and slip rate. The contours express the ratio between slip at depth and surface displacement (e.g., for $1 \mathrm{~m}$ slip top uplift is $0.3 \mathrm{~m}$ ). Positions of the buried anticlinal axes and the paleo-channel south of the river diversion are shown. The geometry and location of the modelled fault are constrained using both geomorphological and subsurface geology observations. The abandonment of the paleochannel and the longitudinal anomalies observed along the Oglio River are induced by fault-related tectonic uplift south of the diversion. Topography is from the Map of Relief and Vertical Movements of the Po Plain (MURST, 1997b).

clines seen in commercial seismic sections or reported in geological maps.

We suggest that the anomalies included in our database represent the surface evidence of growing anticlines driven by blind thrusts. However, only occasionally these anticline do have a discernible morphological expression, probably due to the competition between tectonic rates of vertical displacement and sedimentary rates. We suggest that slip on the blind thrust faults induces slight tilting of the surface that is enough to cause the deflection of the river net- work, even though it does not produce morphological anticlines.

We included in our database 36 drainage anomalies (fig. 5 and table I), most of which occur in the southern part of the plain along tributaries of the Po River flowing down from the Apennines. All the anomalies except for four (\#1, \#2, \#3, and \#4) occur in the stretch of the plain east of Milan. The activity of the buried thrust fronts seems to have controlled also the Po River (\#1, \#32, \#27 and \#19), which exhibits shifts in channel pattern (e.g., anomaly 
\#32) and sudden diversions with abandoned paleo-channels (e.g., anomaly \#27).

The correlation of historical seismicity with some of these faults suggests that at least in some cases they slip seismically. The simple consideration that even in the most active areas of peninsular Italy the average return time for large earthquakes is longer than 1000 years (e.g., fig. 1 in Valensise and Pantosti, 2001a) suggests that current historical catalogues, which are considered complete for earthquakes larger than $M 5.5$ only after the 17 th century A.D., may not cover a full seismic cycle for most of the seismogenic sources of the Po Plain, which could well be the site of very infrequent damaging earthquakes. A comparison between long-term (Upper Pleistocene) and short-term vertical deformation rates, calculated using geomorphic correlations and repeated geodetic measurements respectively (De Martini et al., 1998), indicates that a large fraction of the strain is released aseismically for some of these active thrusts. If extended regionally, this observation would greatly reduce the seismic hazard of the Po Plain. This inference is supported by the difference between the large number of drainage anomalies that may be explained by the activity of blind thrusts, and the few large earthquakes listed in current catalogues.

We applied in detail a morphological analysis to the drainage anomaly shown by the Oglio River near Soncino (CR) (anomaly \# 14). Here we found a potential correlation among a river diversion, the longitudinal anomalies of the river bed (fig. 6a), the presence of a buried anticline, and the occurrence of a $M_{e} 5.7$ earthquake in historical times (fig. 7). Using simple dislocation model we speculate on the position and extent of the area undergoing differential vertical displacements. According to our hypothesis the geomorphic signal can be explained by the coseismic growth of an anticline located south of the diversion, driven by a south-verging, north-dipping blind thrust (fig. 8) belonging to the Southern Alps system. This fault model (Orzinuovi Source) has been included in the Database of Potential Sources for Earthquakes Larger than M 5.5 in Italy (Valensise and Pantosti, 2001b) as a contribution for the seismic hazard assessment of the Po Plain. Four addi- tional sources identified using the same method exist in the area (fig. 1a,b), but only one of them was correlated to an historical earthquake (Bagnacavallo Source, \#5 in fig. 1a and table II, associated with anomaly \#20-21 and 11 April 1688 earthquake in table I).

\section{Acknowledgements}

Part of this study is the result of the research done by F.C. during her M.S. Thesis. Andrew Meigs, Daniela Pantosti, Bob Yeats and an anonymous reviewer are thanked for their thorough revision and for improving the paper.

\section{REFERENCES}

Albarello, D., V. Bosi, F. Bramerini, A. Lucantoni, G. Naso, L. Peruzza, A. Rebez, F. Sabetta and D. SLEJKO (2000): Carte di pericolosità sismica del territorio nazionale, Quad. Geofis., 12, 1-7.

ANDERSON, H.J. and J.A. JACKSON (1987): Active tectonics of the Adriatic region, Geophys. J. R. Aston. Soc., 91 937-983.

Anzidei, M., P. Baldi, G. Casula, A. Galvani, E. Mantovani, A. Pesci, F. Riguzzi and E. Serpelloni (2001): Insights into present-day crustal motion in the Central Mediterranean area from GPS surveys, Geophys. J. Int., 146 (1), 98-110.

Bigi, G., A Castellarin, R Catalano, M Coli, D. Cosentino, G.V. Dal Piaz, F. Lentini, M. Parotto, E. Patacca, A. Praturlon, F. Salvini, R. Sartori, P. SCANDONE and G.B. VAI (1989): Synthetic StructuralKinematic Map of Italy, CNR-Progetto Finalizzato Geodinamica, reprinted in Anatomy of an Orogen: the Apennines and Adjacent Mediterranean Basins, edited by G.B. VAI and I.P. MARTINI (Kluwer Academic Publishers, Dordrecht, 2001), 495-512.

Benedetti, L., P. TAPPONIER, G.C.P. King, B. Meyer and I. MANIGHETTI (2000): Growth folding and active thrusting in the Montello region, Veneto, Northern Italy, J. Geophys. Res., 105 (B1), 739-766.

Bertotti, G., V. Picotti and S. Cloetingh (1998): Lithospheric weakening during «retroforeland» basin formation: tectonic evolution of the Central South Alpine foredeep, Tectonics, 17 (1), 131-142.

Boschi, E., E. Guidoboni, G. Ferrari, D. Mariotti, G. VAlEnSise and P. GASPERINI (2000): Catalogue of strong Italian Earthquakes, 461 B.C. to 1997, Ann. Geofis., 43 (4), 609-868.

BullaRD, T. and W. LeTTIS (1993): Quaternary fold deformation associated with blind thrust faulting, Los Angeles Basin, California, J. Geophys. Res., 98, 8349-8369.

BurnetT, A.W. and S.A. SCHUMM (1983): Alluvial-river response to neotectonic deformation in Louisiana and Mississipi, Science, 222, 49-50. 
Cassano, E., A. Anelli, R. Fichera and V. Cappell (1986): Pianura Padana: interpretazione integrata di dati geologici e geofisici, in Proceedings of the $73^{\circ}$ Meeting of the Società Geologica Italiana, September 29-October 4, 1986, Rome, Italy, pp. 27.

Castiglioni, G.B. and G.B. Pellegrini (Editors) (2001): Note illustrative della Carta Geomorfologica della Pianura Padana, Geogr. Fis. Din. Quat., Suppl. to IV, pp. 207.

Champel, B, P. Van Der Beek, J.L. Mugnier and P. LETURMY (2002): Growth and lateral propagation of fault-related folds in the Siwaliks of Western Nepal: rates, mechanisms, and geomorphic signature, J. Geophys. Res., 107 (B 6), 10.1029/2001JB000578.

Ciucci, F., P. Burrato and G. Valensise (2002): Complex geomorphic response to blind thrust faulting along the northern margin of the Apennines near Mirandola ( $\mathrm{Po}$ Plain), in Proceedings of the ESC Annual Meeting, Genova, Italy, September 2002.

CPTI, Working Group (1999): Catalogo Parametrico de Terremoti Italiani (ING-GNDT-SGA-SSN, Bologna), pp. 88 (http://www.ingv.it).

De Martini, P.M., P. Burrato and G. Valensise (1998): Active tectonic structures in the Padana Plain: new discrimination strategy from a joint study of geomorphic and geodetic leveling data, in Proceedings of the EGS Annual Meeting, Nice, France, April 1998.

Demets, C., R.G. Gordon, D.F. Argus and S. Stein (1994): Effect of recent revisions to the geomagnetic reversal time scale on estimates of current plate motions, Geophys. Res. Lett., 21 (20), 2191-2194.

Dolan, J.F., K. SieH, T.K. RockWELl, R.S. Yeats, J. Shaw, J. Suppe, G.J. Huftile and E.M. Gath (1995): Prospects for larger or more frequent earthquakes in the Los Angeles metropolitan region, Science, 267, 199-205.

Doglioni, C. (1993): Some remarks of the origin of foredeeps, Tectonophysics, 228, 1-20.

Dziewonski, A.M., A. Friedman, D. Giardini and J.H. WoOdHOUSE (1983): Global seismicity of 1982: centroid moment tensor solutions for 308 earhquakes, Phys. Earth Planet. Inter., 33, 76-90.

Elter, P. and P. Pertusati (1973): Considerazioni sul limite Alpi-Appennino e sulle relazioni con l'arco delle Alpi Occidentali, Mem. Soc. Geol. It., 12, 359-375

Ferrarese, F., U. Sauro and C. Tonello (1998): The Montello Plateau, karst evolution of an alpine neotectonic morphostructure, Z. Geomorph. N. F., 109 (Suppl.-Bd.), 41-62.

Frepoli, A. and A. Amato (1997): Contemporaneous extension and compression in the Northern Appennines from earthquake fault-plane solutions, Geophys. J. Int., 129 , 368-388.

Gasperini, P., F. Bernardini, G. Valensise and E. Boschi (1999): Defining seismogenic sources from historical earthquakes felt reports, Bull. Seismol. Soc. Am., 89 (1) , 94-110.

Guccione, M.J., K. Mueller, J. Champion, S. Shepherd, S.D. Carlson, B. Odhiambo and A. Tate (2002): Stream response to repeated coseismic folding, Tiptonville dome, New Madrid seismic zone, Geomorphology, 43, 313-349.

Hauksson, E., L.M. Jones, T.L. Davis, L.K. Hutton, G.
Brady, P.A. Reasenberg, A.J. Michael, R.F. Yerkes, P. Williams, G. Reagor, C.W. Stover, A.L. Bent, A.K. Shakal, C.G. Bufe, M.J.S. Johnston and E. CRANSwiCK (1988): The 1987 Whittier Narrows earthquake in the Los Angeles metropolitan area, California, Science, 239, 1409-1412.

Holbrook, J. and S.A. Schumm (1999): Geomorphic and sedimentary response of rivers to tectonic deformation: a brief review and critique of a tool for recognizing subtle epeirogenic deformation in modern and ancient settings, Tectonophysics, 305, 287-306.

Knighton, D. (1984): Fluvial Forms and Processes (Edward Arnold Ed., London, U.K.), pp. 218.

Lin, J. and R. STEIN (1989): Coseismic folding, earthquake recurrence and the 1987 source mechanism at Whittier Narrows, Los Angeles basin, California, J. Geophys. Res., 94, 9614-9632.

Marchetti, M. (1990): Cambiamenti idrologici nella Pianura Padana Centrale a nord del Fiume Po: i casi di «underfit streams» dei fiumi Mincio, Oglio e Adda, Geogr. Fis. Dinam. Quat., 13, 53-62.

MarchetTi, M. (1996): Variazioni idrodinamiche dei corsi d'acqua della Pianura Padana Centrale connesse con la deglaciazione, Il Quaternario, 9 (2), 465-472.

MARChETTI, M. (2002): Enviromental changes in the Central Po Plain (Northern Italy) due to fluvial modifications and anthropogenic activities, Geomorphology, 44, 361-373.

Massonet, D., M. Rossi, C. Carmona, F. Adragna, G. Peltzer, K. Feigl and T. Rabaute (1993): The displacement field of the Landers earthquake mapped by radar interferometry, Nature, 364, 138-142.

Montone, P. and M.T. MariucCI (1999): Active stress along the NE external margin of the Apennines: the Ferrara arc, Northern Italy, Geodynamics, 28, 251-265.

MURST (1997a): Geomorphological Map of Po Plain, 1:250000 scale (SELCA, Firenze).

MURST (1997b): Map of Relief and Vertical Movements of Po Plain, 1:250000 scale (SELCA, Firenze).

OuCHI, S. (1985): Response of alluvial rivers to slow active tectonic movement, Geol. Soc. Am. Bull., 96, 504-515.

Peakall, J., M. Leeder, J. Best and P. Ashworth (2000): River response to lateral ground tilting: a synthesis and some implications for the modelling of alluvial architecture in extensional basins, Basin Res., 12, 413-424.

Petrucci, F and S. Tagliavini (1969): Note Illustrative della Carta Geologica d'Italia, Foglio 61, Cremona, Servizio Geologico d'Italia, pp. 43.

PIERI, M. and G. GROPPI (1981): Subsurface geological structure of the Po Plain, CNR, P.F. Geodin., Publication n.414, 278-286.

RoberTSON, A.H.F. and M. GRASSO (1995): Overview of the late Tertiary-Recent tectonic and paleo-environmental development of the Mediterranean region, Terra Nova, 7, 114-127.

SCHUMM, S.A. and H.R. KHAN (1972): Experimental study of channel patterns, Geol. Soc. Am. Bull., 83, 1755-1770.

Schumm, S.A., J.F. DumONT and J.M. Holbrook (2000): Active Tectonics and Alluvial Rivers (Cambridge University Press), pp. 290.

Selvaggi, G., F. Ferulano, M. Di Bona, A. Frepoli, R. azzara, A. Basili, C. Chiarabba, M.G. Ciaccio, F. Di 
Luccio, F.P. Lucente, L. MArgheriti and C. Nostro (2001): The $M_{w} 5.4$ Reggio Emilia 1996 earthquake: active compressional tectonics in the Po Plain, Italy, Geophys. J. Int., 144, 1-13.

SHAW, J.H. and J. SuPPE (1996): Earthquake hazards of active blind-thrust faults under the Central Los Angeles Basin, California, J. Geophys. Res., 101, 8623-8642.

SteIN, R.S. and R.S. Yeats (1989): Hidden earthquakes, Sci. Am., 260, 48-57.

Suppe, J., G.T. CHOU and S.C. Hook (1992): Rates of folding and faulting determined from growth strata, in, Trust Tectonics, edited by K.R. McClaY (Chapman and Hall, New York), 105-121.

Valensise, G. and D. PAntosti (2001a): The investigation of potential earthquakes sources in peninsular Italy: a review, J. Seismol., 5, 287-306.
VAlensise, G. and D. PAntosti (Editors) (2001b): Database of potential sources for earthquakes larger than $M 5.5$ in Italy, Ann. Geofis., 44 (suppl. to n. 4), pp. 180, with CD-ROM.

VitToRI, E. and G. VENTURA (1995): Grain size of fluvial deposits and Late Quaternary climate: a case study in the Po River valley (Italy), Geology, 23, 735-738.

WARD, S.N. (1994): Constraints on the seismotectonics of the Central Mediterranean from very long baseline interferometry, Geophys. J. Int., 117, 441-452.

WRIGHT, T.L. (1991): Structural geology and tectonic evolution of the Los Angeles Basin, California, in Active Margin Basin, edited by K.T. Biddle, Mem. Am. Ass. Pet. Geol., 52, 35-134.

YEATS, R.S. (1986): Active faults related to folding, in Active Tectonics, edited by R.E. WALlace (National Academy Press, Washington), 63-79. 